Kadi Polli

\title{
REVIEW: “TAKE HEART, DEAR JULIE!” - MORITZ RUGENDAS AND PAINTER JULIE HAGEN SCHWARZ
}

\section{Exhibition}

"Mut, liebe Julie!" - Moritz Rugendas und die Malerin Julie Hagen Schwarz 18 March - 5 June 2016

Augsburg, Schaezlerpalais and Grafisches Kabinett

\section{Catalogue}

"Mut, liebe Julie!", Moritz Rugendas und die Malerin Julie Hagen Schwarz, hrsg. von Christin Conrad, Christof Trepesch (Augsburg: WißnerVerlag 2016)

We can find a few lucky creators in the art history of the Baltic provinces, whose literary legacy has been preserved to this day and made accessible to the public by a dedicated biographer. For instance, we could mention Johann Wilhelm Krause (1757-1828), who was 
introduced to the readers via hand-written memoirs transcribed in the 1990s by Valentina von Krause; or Franz Gerhard von Kügelgen (1772-1820), whose legacy of pictures and letters has been studied in recent decades by Dr. Dorothee von Hellermann. As a rule, such initiatives presume access to family archives in Germany and elsewhere, and are dependent on the circle of descendants of the artist.

In the past decade, the Hagen family of artists from Tartu has found a biographer of their own: German art historian Christin Conrad has been publishing letters of the most significant Baltic German female artist Julie Hagen-Schwarz as well as her father August Matthias Hagen, a teacher at the drawing school of Tartu University. By now, Epp Preem and Christin Conrad have compiled a number of commented publications with the letters of the Hagens, ${ }^{1}$ and their work continues.

The exhibition on the oeuvre of Julie Hagen-Schwarz, curated by Christin Conrad, has clearly stemmed from the biography and letters of the artist, which is also evident in the intimate tone used for the title: Mut, liebe Julie! ("Take heart, dear Julie!"). Even if the foreword to the exhibition stresses the extensive reach of Julie HagenSchwarz's life from Tartu, Estonia to Germany, Rome and later even to Siberia, the focus of the display is on her learning years in Munich in 1848-1851. In connection to the location of the exhibition in Augsburg by Munich, the curator attempted to find a focal point for the subject matter, a so-to-say local key to make the story of an unknown "Russian lady" more interesting to the visitors of the Schaezlerpalais.

The solution lay in the local Augsburgian painter and explorer of South America, Moritz Rugendas (1802-1858), who met Julie Hagen in Munich in 1848, having just returned from his exotic travels. Although a love affair never really blossomed between the renowned artist and his young protégé - as the press coverage of the exhibition

1 August Matthias Hagen, Kunstniku reisipäevikud 1820-1821, compiled and translated by Epp Preem (Tallinn: Eesti Ajaloomuuseum, 2011); "Leb wohl, leb wohl, Du mein Alles!": der Briefwechse zwischen Emilie Hagen und Ludwig Schwarz in den Jahren seiner ersten sibirischen Expeditionsreise 1847 bis 1853, Bd. I, hrsg. von Christin Conrad (Dresden: Peter Schwarz, 2012); Kaotused ja leidmised. 1854. Julie Hageni poodeline aasta kirjades, compiled by Christin Conrad, translated by Epp Preen (Tallinn: Eesti Ajaloomuuseum, 2013); Uhe eluloo algus: kunstnik August Matthias Hageni (17941878) autobiografia ja tema Livimaa pildid = Anfang einer Lebensgeschichte. die Autobiographie des admits with a certain degree of regret -, the friendship and creative dialogue between Rugendas and Hagen provide a backbone to the exhibition.

The idea behind the display is great: it is based on a fascinating story and relies on captivating key words (female artist from Russia, painters of Munich, salon life, Southern American exotica, and so on), the visual side of it, however, is weaker. It is unfortunate that the organisers of the exhibition have not had possibilities for international loans and thus the selection of artwork remains very limited, including merely pieces from German private collections and Augsburg-based works of art. This means that the friendship and mentorship between Moritz Rugendas and Julie Hagen, which form the core of the concept of the exhibition, has not been played out to the fullest effect as there are only a few works of art from either artist available and nearly none of these carry sufficient visual force, making the communicative aspect of the display rely heavily on the written word, i.e. the accompanying texts and catalogue. The lack of illustrative material to the main theme has been compensated to some extent by supplementing works from other artists in the Munich circle of Rugendas and Julie Hagen as well as examples from Julie Hagen's oeuvre created in the years spent in Rome (1851-1854) or by her circle of acquaintances there (Riedel, Rottmann, Corrodi), plus a couple of pieces by August Matthias Hagen.

To add the complicated spatial solution (the display has been divided in two, based on the source material: paintings can be viewed at the end of the enfilade on the third floor of the Schaetzerpalais, "behind the back" of another temporary exhibition, while sketches and drawings are located on the ground floor of the palace, in the rooms of the Grafisches Kabinett) - and the exhibition becomes visually illegible and fragmented for the visitors. All in all the exhibition seems rather to be a series of images marking the course of research, or vice versa - a justification for the publication of the catalogue.

\section{MUNICH YEARS IN THE CATALOGUE}

The catalogue is definitely the heftiest part of the Augsburg exhibition project as it is the most thorough compilation of research articles, pic- 
ture catalogue, artist biographies and published sources ever issued about Julie Hagen and her circle of acquaintances.

Christin Conrad as the compiler of the catalogue has intentionally left aside the goal of providing an extensive overview of Julie Hagen's oeuvre, and has instead concentrated on her Munich period. In this she has been guided by her interest in the painter's biographical source material, which is also characteristic of the whole Augsburg project. A rather short general introduction to the catalogue is followed by Conrad's opening article "Gestern kam der prächtige Künstler und Mensch Rugendas.. Moritz Rugendas als Mentor der Malerin Julie Hagen in München", which describes Moritz Rugendas and Julie Hagen's friendship in Munich based on quotes from their correspondence. As such, it is an interesting and useful study to give us an idea about Julie Hagen's life in Munich, her personal dilemmas between adapting to the Bavarian art scene and heeding stern advice from her father, who was expecting the daughter to return to Tartu after her studies. Many facts, names and interpersonal relations have become clearer when reading the letters of the Hagens, which has allowed Christin Conrad to make several discoveries about Julie Hagen's oeuvre: to correct attributions of works of art (e.g., a study for Moritz Rugendas's portrait has been linked to Julie Hagen $\left.{ }^{2}\right)$, to determine the people portrayed (e.g., the genre portrait Old Swabian Woman, Cat. No. 12), to see the role models of the painter and to rediscover her lost works (Portrait of Katharina Volz, Cat. No. 13). The studies conducted and new discoveries made have been summarised in the catalogue and list of pictures, and at least through the photographic material it is possible to make comparisons with images from Estonian, Russian and other collections that did not make it to the exhibition.

\section{JULIE HAGEN AS ANGELICA II}

The special part of the catalogue is the theme of female artists - Julie Hagen's position in the Munich art scene and other women painters

2 Work of art located in the Art Museum of Estonia EKM VM 685: "Mut, liebe Julie!" Moritz Rugendas und die Malerin Julie Hagen Schwarz, Ausstellungskatalog, hrsg. von Christin Conrad, Christof Trepesch (Augsburg: Schaezlerpalais und Grafisches Kabinett Augsburg, 2016), 14, Cat.

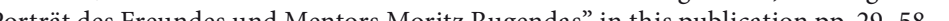

around her. Thus, the artist's letters are of enormous value in shedding light on the personalities, views and professional ambitions of contemporary women, making her comparable to Angelica Kauffmann.

Bärbel Kovalevski, who has been studying German female artists for decades, has written an excellent overview article "Hier in der reichen herrlich glänzenden Residenz... Frauenkunststudium in München um 1850 am Beispiel von Julie Hagen Schwarz" on the Munich art scene and women's participation therein in the mid- $19^{\text {th }}$ century. Her article highlights the conservative framework of Julie Hagen's learning years: certain openness towards feminine artistic talent, which came with the Enlightenment and made it possible for nearly 50 women to enter the Academy of Fine Arts, Munich, in the first half of the $19^{\text {th }}$ century, had been left in the past by the 1840s in German art metropolises, so Julie Hagen's best chance in Munich was to study in the studio of the portrait artist Joseph Bernhardt (1805-1885), who was the only one dealing with lady students. Kovalevski's article includes Julie Hagen's letters to her parents in Tartu, which give us valuable glimpses into the daily art life in Munich outside the Art Academy and into the administrative and academic organisation of Bernhardt's painting school of approximately 25 pupils. Hagen's correspondence brings back to life several of her co-students: German painters who have been nearly forgotten by now, such as Lina List (1829-1911) or Marie Berger-Lattner (1825-?), who shared lodging with Hagen over the years at Bernhardt's school.

A few of the ladies included in Hagen's letters, more specifically two painters of Augsburgian origin: Lina List and Helisena Girl (18311916), have been dedicated a separate article in the catalogue by Lena Elashmawy under the heading "Die Malerinnen Lina List und Helisena Girl. Eine Freundschaftsskizze um Julie Hagen, dokumentiert aus Briefe". Covered personal histories, thoughts and relations serve as wonderful illustrations to the conflict between female gender roles and professiona self-fulfilment in the $19^{\text {th }}$ century, adding details to the image of Julie Hagen, who stood apart from the other women in Bernhardt's painting school for her good previous training (in addition to the skills acquired under her father August Matthias Hagen, Julie Hagen has spent a year copying in Dresden's painting gallery before arriving in Munich) as well as the seriousness of her artistic ambitions. 


\section{MALE ARTISTS AROUND JULIE HAGEN}

Despite the catalogue's general focus on Munich it includes Gerd-Helge Vogel's overview “August Matthias Hagen (1794-1878) - Vater und erster Lehrer Julie Hagens". Of all the authors in the catalogue, Vogel is the best versed in Baltic German art and circumstances; however, his interest in the painter's father, Tartu artist August Matthias Hagen is limited to the style and language of forms in the latter's oeuvre. Hence he primarily deals with the stylistic links of Hagen's work to the most renowned master of German Romanticism, Caspar David Friedrich, which point has been already made in a number of earlier publications. ${ }^{3}$ A. M. Hagen's relationship with his daughter and attitude towards her work have not been mentioned at all, in spite of the promising title of the article.

Dr. Ulrich Schulte-Wülwer, a long-time director of Flensburg Art Museum, has written a monographical article on the genre painter Ernst Meyer, a Jew who studied in Copenhagen and became popular in Italy in the 1820s and 30s, who was well-known in the European art scene for his extensive circle of acquaintances and travel experience. In 1848 in Munich and in 1851 in Rome he also briefly came in contact with Julie Hagen-Schwarz.

The last article in the catalogue is by Chilean researcher Pablo Diener who provides an overview of Moritz Rugendas's late oeuvre. For Diener, the letters written by Julie Hagen give additional information about the life of Rugendas as the final decade of his life in Europe is relatively obscure in comparison to his well-documented travels and works of art created in Brazil, Mexico, Chile, Argentina and elsewhere. Through Hagen's letters we can see the friendship that forms the focal point of the exhibition from two angles: on the one side they describe Moritz Rugendas's mentorship of the young female artist, who can enter the Munich artistic society and exhibition scene with the support of her distinguished patron - which is Christin Conrad's approach in her article. On the other side, the friendship also played an important role for Rugendas, who suffered from lack of recognition and creative crisis in his homeland and who found strength from Hagen's admiration and

3 Exhibition catalogue Caspar David Friedrich \& the German Romantic Landscape, ed. by Hermitage Amsterdam (Aldershot: Lund Humphries, 2008), 30-31, 72-73. The oeuvre of August Matthias Hagen has recently been expanded on by Gerd-Helge Vogel in the same context of German romanticists an in the light of Caspar David Friedrich's examples and Carl Gustav Carus's landscape painting theo-
ries in the Baltic Journal of Art History, 10 (2015), 11-50. support, specifically in the brokering of works of art by the Hagens for Baltic art collections and the joint sales exhibition of the works of art by A. M. Hagen, Julie Hagen and Moritz Rugendas in Tartu in the winter of $1850-1851$.

Similarly to the exhibition, most of the articles have been titled with quotes from Julie Hagen's correspondence, emphasising the (auto-)biographical nature of this exhibition and catalogue project. The Hagen family archive is an extraordinary treasure trove, offering a wealth of intriguing topics from the aspect of gender studies or Baltic art history, be it the tense relations between the father and daughter, the patronising discussion between Rugendas and August Matthias Hagen as to "Julie's lack of prerequisites to becoming a history painter", or Car Tiomoleon von Neff's critical attitude, bordering on rudeness, towards the compatriot female painter.

The catalogue serves as a wonderful overview of Julie Hagen's years in Munich while also shedding light on a few other female painters who studied at Bernhardt's studio together with her. In contrast, Hagen's Baltic German roots, her Rome period (1851-1854) and late oeuvre are barely mentioned at the exhibition and in the catalogue; these years are still to be looked at with a fresh and discerning eye in text and image.

The study on Julie Hagen-Schwarz has a way to go to be comparable to Dr. Dorothee von Hellermann's achievement: catalogue raissone of the oeuvre of Franz Gerhard von Kügelgen ${ }^{4}$. Nevertheless, Christin Conrad seems to be taking steps in the same direction. It is laudable that Julie Hagen's letters get published and her works of art get mapped; the next stage is to leave aside the mere study of sources in order to look at Julie Hagen via different thematic exhibitions and articles.
Dorothee von Hellermann, Gerhard von Kügelgen (1772-1820). Das zeichnerische und malerische Werk (Berlin: Reimer, 2001). 
CV:

Kadi Polli is the director of the Kumu Art Museum (Art Museum of Estonia). She studied art history at the University of Tartu, at the University of Kiel and at the Estonian Academy of Arts. In 2002-2013 she was the director of the Kadriorg Art Museum (Art Museum of Estonia), in 2013-2016 a lecturer in the Department of Art History at the University of Tartu. Her main research field is Baltic visual culture and the art scene in the $18^{\text {th }}$ and $19^{\text {th }}$ centuries. She has curated international exhibitions of European and Baltic art, for example, The Swiss Muse. Angelica Kauffmann (2004), Dreaming about Mountains. Swiss Landscapes in Baltic Art (2008) and Between Dresden and St. Petersburg. Artist Twin Brothers von Kügelgen (2015). She has published scholarly articles and co-authored various catalogues and collections of articles. Kadi Polli is currently Chair of the Board of the Estonian Society of Art Historians and Curators. 